Table 1. The reaction at $\mathrm{pH} 5 \cdot 3$ between pepsin and different solutions containing fibrinogen

$\begin{array}{lc} & \begin{array}{c}\text { Pepsin required to protect } \\ 1 \text { g. of fibrinogen against } \\ \text { (NH, })_{2} \mathrm{SO}_{4} \text { precipitation } \\ \text { at 21.6\% saturation } \\ \text { Fibrinogen-containing }\end{array} \\ \text { solution used } & 0.9 \\ \text { Plasma } & 0.02 \\ \text { Fibrinogen } & 1.05 \\ \text { Solution of fibrinogen and } & \\ \text { pepsin inhibitor } & 1.8 \\ \text { Fibrinogen and serum } & 0.06 \\ \text { Fibrinogen and heated serum } & 0.08 \\ \text { Fibrinogen and heated defi- } & \\ \text { brinated plasma } & \end{array}$

\section{DISCUSSION .}

Because of the close association between the pepsin inhibitor and fibrinogen, and because fibrinogen solutions could be approximately titrated against pepsin, it was decided to use the pepsin-fibrinogen reaction as a measure of the purity of fibrinogen solutions. The results show that four or five reprecipitations with $21 \cdot 6 \%$ sat. $\left(\mathrm{NH}_{4}\right)_{2} \mathrm{SO}_{4}$ are necessary to separate the pepsin-inhibitor from fibrinogen. The concentration of $\left(\mathrm{NH}_{4}\right)_{2} \mathrm{SO}_{4}(21.6 \%$ sat. $)$ used in this work was determined by preliminary experiments to be a safe minimum quantity for the precipitation of the fibrinogen from the plasma used. Most other workers have used 25\% saturation. 1 g. of pepsin (1/3000 U.s.P.) will protect approximately $50 \mathrm{~g}$. of our purest preparations of fibrinogen against precipitation with $\left(\mathrm{NH}_{4}\right)_{2} \mathrm{SO}_{4}$. Similar values have been obtained by using fibrinogen solutions prepared from different plasmas.
Little or no pepsin inhibitor could be demonstrated in plasma defibrinated by heating, or in serum which had been heated to $58^{\circ}$. However, the pepsin inhibitor is apparently stable at $55^{\circ}$, since serum heated to this temperature showed no loss of potency. It was present, together with the serum globulins, in the filtrates obtained during the preparation of fibrinogen, and was precipitated therefrom by precipitating with $50 \%$ sat. $\left(\mathrm{NH}_{4}\right)_{2} \mathrm{SO}_{4}$. On adding this precipitate to a purified fibrinogen solution, the reaction between the mixture and pepsin was similar to that between plasma and pepsin. This pepsin-inhibitory action of serum appeared to be greater than that in the plasma. from which the serum had been prepared.

\section{SUMMARY}

1. A substance ('pepsin-inhibitor') is present in fresh serum and plasma, which inhibits the ability of pepsin to protect fibrinogen against precipitation at $p \mathrm{H} 5 \cdot 0-5 \cdot 6$ by low concentrations of salt.

2. This pepsin inhibitor is present in preparations of fibrinogen precipitated with $20-25 \%$ sat. $\left(\mathrm{NH}_{4}\right)_{2} \mathrm{SO}_{4}$, but separation of it from fibrinogen can be effected by repeated precipitation of the latter with $21 \cdot 6 \%$ sat. $\left(\mathrm{NH}_{4}\right)_{2} \mathrm{SO}_{4}$.

3. Heating at $58^{\circ}$ for 2 min. destroys almost all the activity of preparations of this 'pepsin-inhibitor'.

I am indebted to the Medical Director of this Institute for providing facilities for carrying out these experiments and to Mr L. N. Owen who has performed much of the experimental work.

\title{
REFERENCES
}

Ferguson, J. H. [1938-9]. J. Lab. clin. Med. 24, 273.

\& Erickson, B. N. [1939]. Proc. Soc. exp. Biol., N.Y., 40, 427.

Florkin, M. [1930]. J. biol. Chem. 87, 629 .
Hind, H. G. [1943]. Biochem. J. 37, 289.

Warner, E. D., Brinkhous, K. M. \& Smith, H. P. [1935-6]. Amer. J. Physiol. 114, 667.

\section{Microdetermination of Vitamin A and Carotenes}

By F. URBAN AND B. MILDER, Department of Biological Chemistry, Washington University, AND C. CARRUTHERS, Research Department, The Barnard Free Skin and Cancer Hospital, St Louis, Mo., U.S.A.

The Carr-Price reaction has been widely used for the estimation of vitamin $A$ and carotenes. The limitations and difficulties of the method have been described by so many that no attempt will be made to review the extensive literature [see Brode \& Magill, 1931]. The conventional method, as used by
May,-Blackfan, McCreary \& Allen [1940] and by Dann \& Evelyn [1938] for the determination of $\beta$-carotene by measuring the light absorption with a $440 \mathrm{~m} \mu$ filter, is not specific. For example, in blood serum both bilirubin and $\beta$-carotene absorb light of wave-length $440 \mathrm{~m} \mu$. 
The optical method described here was developed to overcome the difficulties in the quantitative estimation of the free* vitamin A. The application of the same method for the accurate determination of $\beta$-carotene has been studied. The instrument is an adaptation of a photoelectric colorimeter developed by Yntema \& Fleetwood [1937]. It differs from it in one fundamental respect. A beam of light after having traversed the sample (Carr-Price reaction) is split into two beams which pass through 620 and $589 \mathrm{~m} \mu$ filters, respectively, before reaching two reeording photocells. Thus a direct simultaneous and mutually independent determination of vitamin $A$ and carotene in one and the same sample can be achieved, providing that (1) the beams are monochromatic, or nearly monochromatic; (2) the temperature is close to $Q^{\circ}$ (cold room). On the other hand, only vitamin A can be determined with this apparatus at room temperature, because the $589 \mathrm{~m} \mu$ band of $\beta$-carotene fades within a few seconds.

\section{EXPERIMENTAL}

The apparatus used for measuring the intensity of the blue colour produced by the reaction of vitamin A with $\mathrm{SbCl}_{3}$ is shown diagrammatically in Fig. 1. The accessories are described in the diagram.
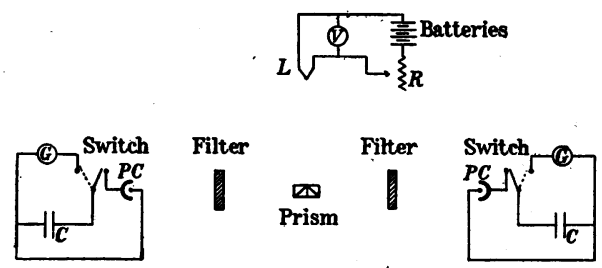

Fig. 1. Circuit for vitamin A: batteries, 6 V.; lamp, 100 c.p. 6-8 V.; rheostat, $0.5 \mathrm{ohm}$.; voltmeter, 0-8; photocells, RCA 922. Circuit for $\beta$ carotene: galvanometers, $L-N$ R $2500 f$; condensers, L-N $1 \mu \mathrm{F}$; switches, spot; filter, Pyrex $625 \mathrm{~m} \mu$ no. 245; filter, $589 \mathrm{~mm}$.

The light source was a Mazda lamp, 100 c.p., 6-8 V., supplied by batteries, constant voltage being maintained by means of a rheostat and voltmeter. A glass-stoppered cell, $1 \mathrm{ml}$. in capacity and $5 \mathrm{~cm}$. long, as shown in Fig. 2, contained the solutions for the Carr-Price reaction. This cell was in position between the light source and a set of two prisms which served to divide the light which had traversed the solution into two beams, one beam passing through the $620 \mathrm{~m} \mu$ filter to one recording photocell for vitamin $A$, and the other beam (not used in this investigation) passing through the $589 \mathrm{~m} \mu$ filter to

* The term 'free vitamin $A$ ' as here used refers to vitamin A alcohol, or vitamin A ester. We have some evidence that vitamin A may be found in a compound with other carotenoids. the other photocell which measures $\beta$-carotene. The current generated by the influence of light upon the photoelectric cells is stored in the condensers and is measured by determining the sudden deflexion induced by discharging these through a ballistic galvanometer.

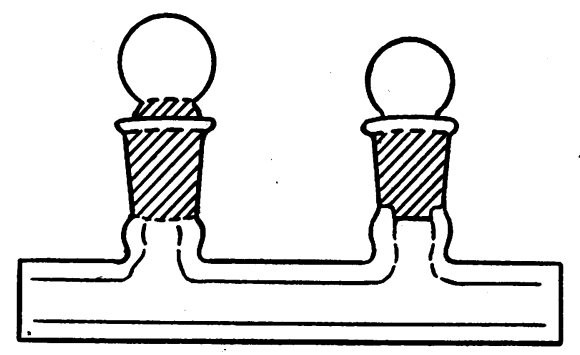

Fig. 2.

The procedure for the determination of vitamin A at room temperature was standardized as follows. A vitamin A concentrate containing 200,000 U.S.P. units/g. was dissolved in chloroform (reagent quality) so that $0.5 \mathrm{ml}$. contained from 10 to 100 U.s.P. units. To the cell (Fig. 2), $0.5 \mathrm{ml}$. of the standard containing a known amount of vitamin A was added. To this was added $\mathbf{0 . 5} \mathrm{ml}$. of a saturated solution of $\mathrm{SbCl}_{3}$ in $\mathrm{CHCl}_{3}$ to develop the colour. Just as the solution of the latter was released from the pipette, a stop-watch was started. The contents of the cell were thoroughly mixed and the cell was placed in the receiver: After exactly $\frac{1}{2} \mathrm{~min}$. the light was turned on at a potential of $5 \mathrm{~V}$. and allowed to pass through the solution in the cell for precisely $1 \frac{1}{2} \mathrm{~min}$.; then the current stored in the

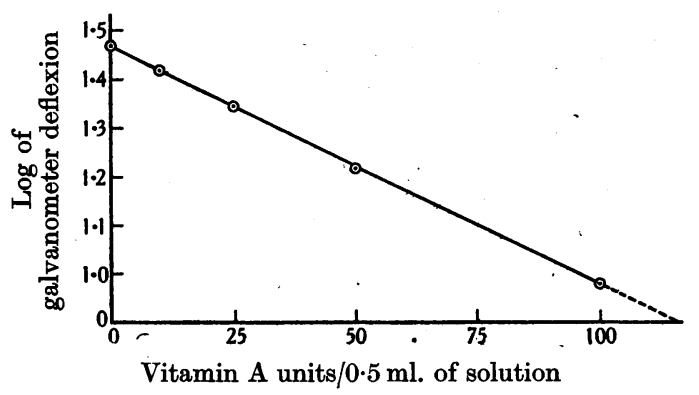

Fig. 3.

condenser was determined by measuring the extent of the galvanometer deflexion. Repetition with varying amounts of vitamin $A$, from 0 to 100 U.S.P. units, and the plotting of the logarithms of the galvanometer deflexions against the U.s.P. units of vitamin A, resulted in a straight line (Fig. 3). To determine the vitamin $\mathbf{A}$ content of an unknown. material dissolved in $\mathrm{CHCl}_{3}$, the above procedure was followed. From the logarithm of the galvano- 
meter deflexion, the amount of vitamin A was easily read off the chart.

Since the absorption band at $589 \mathrm{~m} \mu$ for $\beta$-carotene persists for only 5-10 sec. at room temperature, it is impossible to estimate this substance by measuring the density of the $589 \mathrm{~m} \mu$ band at $20-25^{\circ}$. However, we found that if the Carr-Price reaction is carried out in a cold room at $0^{\circ}$, the $589 \mathrm{~m} \mu$ band could be observed for a period of more than 2 min. when 2-4 vol. $\mathrm{SbCl}_{3}$ (sat. at $0^{\circ}$ ) were added to 1 vol. $\beta$-carotene. The period during which the $620 \mathrm{~m} \mu$ band for vitamin $A$ is observable can also be prolonged at the same temperature. Ender [1932] has shown that the substance responsible for the blue colour produced by the reaction of $\mathrm{SbCl}_{3}$ with carotenoids is more stable at lower temperatures.

The advantages and accuracy of this method over the visual and photoelectric colorimetric methods are obvious. The difficulty of measuring precisely the maximum of the absorption point for blue colour produced by vitamin $\mathbf{A}$ or $\beta$-carotene with $\mathrm{SbCl}_{3}$ is obviated, and the interference by other carotenoids is eliminated by using appropriate filters. The method would serve admirably for the estimation of small amounts of vitamin $A$ and $\beta$-carotene in blood, subject to the temperature limitations discussed above; it is about 50 times as sensitive as the one of Dann \& Evelyn [1938]; at $0^{\circ}$ it is perhaps over 100 times as sensitive.

Since the cells used for the Carr-Price reaction have a tendency to develop, with use; a thin lightabsorbing film of the hydrolysis products of $\mathrm{SbCl}_{3}$, it is imperative that the cells be rigorously cleaned after every determination as follows: the cells* and stoppers were immersed in strong $\mathrm{HCl}$ for several minutes. After removing excess $\mathrm{HCl}$ with tap water, the cells were allowed to stand in chromic acid cleaning solution for $10 \mathrm{~min}$. This was followed by thorough rinsing with tap water followed by distilled water, after which the cells were dried at $100-105^{\circ}$ for $\frac{1}{2} \mathrm{hr}$.

The method has been used for the estimation of vitamin A in mouse and rat livers. The livers were saponified and extracted with peroxide-free ether according to the procedure of Davies [1933]. Spectroscopically the Carr-Price reaction with the unsaponifiable fraction of mouse livers gave only one visible absorption band, that at $620-625 \mathrm{~m} \mu$.

The $\mathrm{CHCl}_{3}$ solution of the unsaponifiable fraction of rat livers showed two absorption bands when treated with $\mathrm{SbCl}_{3}$, one at $620 \mathrm{~m} \mu$ and the other at $570 \mathrm{~m} \mu$. However, after 30 sec., at which time the determinations were made, no interference with the

* The cells were made by the American Instrument Co., Silver Spring, Maryland. The end-plates of each cell were fused to the body of the cell so that cleaning could be carried out in chromic acid cleaning solution. measurement of the density of the $620 \mathrm{~m} \mu$ band was observed spectroscopically. For the determination of vitamin $A$ in the unsaponifiable fraction, or in the fat-soluble fraction of tissues or other substances, it was first necessary to make a spectroscopic examination of the Carr-Price reaction so as to determine whether there was any interference with the measurement of the density of the $620 \mathrm{~m} \mu$ band by other carotenoids. In our experiments this precaution was necessary because a glass filter (Corning 246 R.M. $3.5 \mathrm{~mm}$.) transmitting a band in the red region of the spectrum, rather than a source of monochromatic light, was used.

To follow changes in the hepatic vitamin A content of rats, two groups of animals received intraperitoneal injections at regular intervals of methylcholanthrene and 3:4-benzpyrene dissolved in lard. (Goerner \& Goerner [1939] and Baumann, Foster \& Lavik [1941] have shown that carcinogens cause a lowering of the hepatic vitamin A content of rats.)

During the treatment some of the rats were killed and the vitamin $\mathbf{A}$ content was determined with $0.5 \mathrm{ml}$., or with a $1 / 50$ th part, of the $\mathrm{CHCl}_{3}$ solution of the unsaponifiable fraction. The marked depletion of the liver stores of the vitamin are shown in Table 1.

Table 1. Effect of carcinogens on hepatic vitamin $A$

$\begin{array}{cccc}\text { Animal } & \begin{array}{c}\text { Total dose } \\ \text { of hydro- } \\ \text { carbon } \\ \text { mo. }\end{array} & \begin{array}{c}\text { Vitamin A/ } \\ 0.5 \mathrm{ml} . \\ \text { aliquot } \\ \text { U.s.P. units }\end{array} & \begin{array}{c}\text { Vitamin A/g. } \\ \text { liver } \\ \text { U.s.P. units }\end{array} \\ \text { N 1 } & 0 & 32 & 106 \\ \text { N } 2 & 0 & 56 & 249 \\ \text { N 3 } & 0 & 40 & 160 \\ \text { N 4 } & 0 & 48 & 247 \\ \text { MC 1 } & 16 & 13 & 73 \\ \text { MC 2 } & 16 & 2 & 16 \\ \text { MC 3 } & 16 & 0 & 0 \\ \text { BP 1 } & 16 & 3 & 13 \\ \text { BP 2 } & 16 & 5 & 24 \\ \text { BP 3 } & 16 & 12 & 68\end{array}$

Animals marked $\mathrm{N}$ represent the normal untreated animals; MC, methylcholanthrene treated; BP, benzpyrene treated.

The determination of 2-15 U.S.P. units in $0.5 \mathrm{ml}$. of solution demonstrates the micro nature of the method. The maximum error in the determinations of 10-100 U.s.P. units was $3 \%$. It should not be difficult to develop procedures for the use of this method to determine vitamin $A$ at room temperature for other tissues, or for both vitamin $\mathbf{A}$ and $\beta$-carotene at $0^{\circ}$.

\section{SUMMARY}

A micro-method for the estimation of vitamin $A$ is described. Under proper conditions it can be used for the simultaneous and mutually independent 
determination of vitamin $A$ and $\beta$-carotene in the same sample. The application of the method for the determination of vitamin $A$ in mouse and rat livers is briefly discussed.
The authors are indebted to Dr Samuel M. Gordon, Endo Products, Inc., 395 Fourth Avenue, New York, and to the American Research Products, Minneapolis, Minnesota, for the supply of the distilled vitamin A concentrates; to Dr H. F. Seibert, S.M.A. Corporation, for the $\beta$-carotene.

\title{
REFERENCES
}

Baumann, C. A., Foster, E. G. \& Lavik, P. S. [1941]. J. Nutrit. 21, 431.

Brode, W. R. \& Magill, M. A. [1931]. J. biol. Chem. 92, 87.

Dann, W. J. \& Evelyn, K. A. [1938]. Biochem. J. 32, 1008.

Davies, A. W. [1933]. Biochem. J. 27, 1770.
Ender, F. [1932]. Biochem. J. 26, 1118.

Goerner, A. \& Goerner, M. M. [1939]. J. Nutrit. 18, 441.

May, C. D., Blackfan, K. D., McCreary, J. R. \& Allen, F. H. [1940]. Amer. J. Dis. Child. 59, 1167.

Yntema, L. F. \& Fleetwood, C. W. [1937]. Thesis. St Louis University, St Louis, Mo., U.S.A.

\section{The Microbiological Assay of Riboflavin. The Influence of Inorganic Gonstituents and Unknown Growth Factors}

\author{
By F. W. CHATTAWAY, FRANK C. HAPPOLD AND MARY SANDFORD, \\ From the Biochemical Laboratories, School of Medicine, University of Leeds
}

(Received 12 December 1942)

We are here concerned with the assay of riboflavin which has developed from the investigations of Snell \& Strong [1939] and which showed the linear relationship between the acid production from glucose by Lactobacillus casei $\epsilon$ (Helveticus) and the concentration of riboflavin present in the medium. In this paper the effect of the addition of various inorganic constituents on the microbiological assay of riboflavin will be discussed, and suggestions made for the improvement of the method.

\section{EXPERIMENTAL}

The basal medium of Snell \& Strong [1939] has been modified a number of times, notably by Snell \& Wright [1941], Hutchings, Peterson \& Shull [1942], and Lindner \& Pollack [1942], mainly by the addition of substances which might function as growth factors or accessories. In our view the only real source of variation in the preparation of this medium is in the composition of the acid hydrolysate of casein. We have invariably prepared our hydrolysate according to the method used in $\mathrm{J} . \mathrm{H}$. Mueller's laboratory and described as Method 1 [Johnson \& Mueller, 194i]. This hydrolysate is practically free from $\mathrm{Fe}$ and $\mathrm{P}$ and there is little, if any, Ca present.

The results which follow were obtained with a $20 \%$ acid digest of casein, whose free $\mathrm{HCl}$, when neutralized, gives $3.44 \mathrm{~g}$. $\mathrm{NaCl} / 100 \mathrm{ml}$. $(1 \cdot 72 \mathrm{~g}$. $\mathrm{NaCl} / 1$. of medium). It contains $19.46 \mathrm{~g} . \mathrm{N}_{2} / 1$., no $P$, and the $F e$ content is very smalt.

The basal medium first used was as follows: $50 \mathrm{ml}$. casein hydrolysate $(20 \%) ; 2 \mathrm{ml} .20 \%$ cystine solution in $2 \cdot 5 \mathrm{~N} \mathrm{HCl} ; 0 \cdot 1 \mathrm{~g}$. l-tryptophan; $10.0 \mathrm{~g}$. glucose; $0.5 \mathrm{~g} . \mathrm{KH}_{2} \mathrm{PO}_{4} ; 100 \mu \mathrm{g}$. nicotinic acid; $50 \mu \mathrm{g}$. pantothenic acid; $50 \mu \mathrm{g}$. $p$-amino-benzoic acid; $2.5 \mathrm{ml}$. liver eluate; $0.4 \mathrm{mg}$. $\mathrm{FeSO}_{4} \cdot 7 \mathrm{H}_{2} \mathrm{O}$; $2.0 \mathrm{ml}$. mineral solution.

This was adjusted to $p H \quad 6.8$ and the volume made up to $1 \mathrm{l}$.; the medium was sterilized for $10 \mathrm{~min}$. at $10 \mathrm{lb} . / \mathrm{sq}$. in.

The mineral solution contained: $22.5 \mathrm{~g} . \mathrm{MgSO}_{4}$. $7 \mathrm{H}_{2} \mathrm{O} ; 5 \cdot 0 \mathrm{ml} . \mathrm{CuSO}_{4} .5 \mathrm{H}_{2} \mathrm{O}(1 \% \mathrm{w} / \mathrm{v}) ; 4.0 \mathrm{ml}$. $\mathrm{ZnSO}_{4} .7 \mathrm{H}_{2} \mathrm{O}(1 \% \mathrm{w} / \mathrm{v}) ; 1.5 \mathrm{ml} . \mathrm{MnCl}_{2} .4 \mathrm{H}_{2} \mathrm{O}(1 \%$ w/v); $3.0 \mathrm{ml}$. conc. $\mathrm{HCl} ; \mathrm{H}_{2} \mathrm{O}$ to $100 \mathrm{ml}$.

After sterilization in $20 \cdot \mathrm{ml}$. amounts in $125 \mathrm{ml}$. Pyrex flasks, riboflavin, or extracts of the food to be tested, were added in variable amounts and also $0.2 \mathrm{ml}$. of $0.5 \%(\mathrm{w} / \mathrm{v}) \mathrm{CaCl}_{2}$.

The $\mathrm{CaCl}_{2}$ was added since it.was soon observed that in the absence of such addition, growth and acid production were negligible.

It will be noticed that the medium contains $p$-amino-benzoic acid. In the examination of the partially purified liver fraction it became apparent that this compound was present in the active material. Tests revealed the fact that the compound was a growth stimulant for the Lactobacillus and it was consequently included in the basal medium.

\section{Preparation of active liver extracts}

In early assay methods [Snell \& Strong, 1939] photolysed peptone and yeast extract were added to the food medium; subsequently it was suggested that nicotinic acid and pantothenic acid could replace the yeast extract. In our experience this was 